\title{
Immune Characterization of C-Type Lectin-Like Protein in Rainbow Trout
}

\author{
Jiaqing Wang ${ }^{1}$, Irina Yu. Potoroko ${ }^{*}$, Lina A. Tsirulnichenko ${ }^{2}$ \\ ${ }^{1}$ Shenyang Institute of Technology, Dalian, China \\ 2South Ural State University, Chelyabinsk, Russian Federation, *e-mail: potorokoii@susu.ru
}

Keywords:
C-type lectin;
Om-CTLP;
qRT-PCR;
mRNA expression;
Innate immunity

For citation: Jiaqing Wang, Irina Yu. Potoroko, Lina A. Tsirulnichenko. Immune Characterization of C-Type Lectin-Like Protein in Rainbow Trout. Индустрия nuтания|Food Industry. 2018. Vol. 3, No. 4. C. 88-96. DOI 10.29141/2500-1922-2018-3-4-11

\begin{abstract}
C-type lectins play crucial roles in innate immunity and pathogen recognition. In this study, a C-type lectin-like protein (Om-CTLP) gene was cloned from rainbow trout, Oncorhynchus mykiss by rapid amplification of cDNA ends (RACE) PCR. The full-length CDNA of Om-CTLP was composed of 1,153 bp with a 723 bp open reading frame (ORF) that encodes a 240-residue protein with an estimated molecular mass of $27 \mathrm{kD}$ and a predicted isoelectric point of 5.48. The deduced amino acid sequence of Om-CTLP possessed all conserved features crucial for the fundamental structure, such as the four cysteine residues (Cys ${ }^{128}{ }_{-} \mathrm{Cys}^{230}, \mathrm{Cys}^{207}$ $\mathrm{Cys}^{222}$ ) formed the carbohydrate recognition domain (CRD) internal disulfide bridges and the potential $\mathrm{Ca}^{2+} /$ carbohydrate-binding sites. Om-CTLP contains a transmembrane domain and a single CRD. Om-CTLP showed high similarity of $44 \%-84 \%$ with C-type lectins from other fish species. Quantitative RT-PCR (qRT-PCR) analysis showed Om-CTLP mRNA was constitutive expression in gill, heart, liver, kidney, intestine, spleen and muscle tissues in healthy fish and up-regulated under infection by bacteria or viruses. After being infected by Aeromonas hydrophila or viral haemorrhagic septicemia virus (VHSV), the expression of Om-CTLP were up-regulated from $12 \mathrm{~h}$ post-injection and lasted until the fish became moribund $(P<0.05)$. The recombinant Om-CTLPCRD can agglutinate both Gram-positive (Staphylococcus aureus) and Gram-negative bacteria ( $A$. hydrophila) in a $\mathrm{Ca}^{2+}$-dependent manner. Further analysis showed that the recombinant Om-CTLP can directly bind to all tested microorganisms (S. aureus, Bacillus thuringiensis, Bacillus subtilis, Escherichia coli, Vibrio natriegens, Vibrio parahaemolyticus, and A. hydrophila). These results suggest that Om-CTLP may have important roles in anti-bacterial and anti-viral immunity of rainbow trout.
\end{abstract}

\section{Иммунная характеристика лецитиноподобного белка типа С у радужной форели}

\author{
Дж. Вангㄱ, И.Ю. Потороко ${ }^{2 *}$ Л.А. Цирульниченко ${ }^{2}$ \\ ${ }^{1}$ Шэньянский технологический институт, г. Далянь, Китай

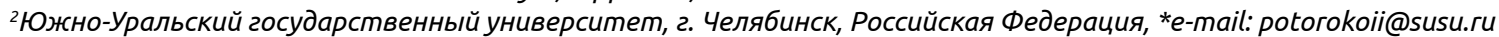

Ключевые слова:

лектин типа $C$;

лектин-подобный белок тuпа $C$ радужной форели;

ОТ-ПЦР;

\section{Реферат}

Лектины типа С играют определяющую роль в формировании врожденного иммунитета и распознавании патогенов радужной форели. В ходе данного исследования, из радужной форели (Oncorhynchus mykiss) был выделен лектин-подобный белок типа С (а6бр. CTLP) методом ПЦР с быстрой амплификацией комплементарной ДНК (кДНК). Идентифицированная кДНК лектин-подобного белка типа С радужной форели состояла из 1153 пар нуклеотидных оснований, из которых 723 пары с от- 
экспрессия иРНК;

врожденный

иммунитет

\begin{abstract}
крытой рамкой считывания (а6бр. ORF) кодировали остаток 240 белка с расчетной молекулярной массой 27 кД и изоэлектрической точкой 5,48. Установленная аминокислотная последовательность лектин-подобного белка типа С радужной форели обладала свойствами, необходимыми для базовой структуры, такими как четыре цистеиновых остатка (Cys ${ }^{128}-\mathrm{Cys}^{230}$, Cys $^{207}-\mathrm{Cys}^{222}$ ), образующих доменоносители углеводов (CRD); внутренние дисульфидные связи и участки потенциального связывания $\mathrm{Ca}^{2+}$ и углеводов. Лектин-подобный белок типа С радужной форели содержит трансмембранный домен и одиночный доменоноситель углеводов и продемонстрировал высокое (44-84 \%) сходство с лектинами С-типа других видов рыб. Количественный анализ ОТ-ПЦР (qRT-PCR) показал, что лектин-подобный белок типа С радужной форели является результатом конститутивной экспрессии в жаберных, сердечных, печеночных, почечных, кишечных, селезеночных и мышечных тканях здоровых рыб и активируется при инфицировании бактериями или вирусами (патогенами). После заражения гидрофильной аэромонадой (Aeromonas hydrophila) или вирусной геморрагической септицемией (VHSV) количество лектин-подобного белка типа С радужной форели активировалось в течение 12 ч после дополнительного впрыска и продолжалось до момента гибели рыбы $(P<0,05)$. Рекомбинатные доменоносители углеводов лектин-подобного белка типа С радужной форели могут агглютинировать как грамположительные (золотистый стафилококк), так и грамотрицательные бактерии ( $A$. hydrophila) путем связывания Ca ${ }^{2+}$. Дальнейший анализ показал, что рекомбинантный лектин-подобный белок типа С радужной форели может напрямую связываться со всеми тестируемыми микроорганизмами (S. aureus, Bacillus thuringiensis, Bacillus subtilis, Escherichia coli, Vibrio natriegens, Vibrio parahaemolyticus, A. hydrophila). Эти результаты свидетельствуют о том, что лектин-подобный белок типа С радужной форели может играть значительную роль в антибактериальном и противовирусном иммунитете радужной форели.
\end{abstract}

Для цитирования: Дж. Ванг, И.Ю. Потороко, Л.А. Цирульниченко. Иммунная характеристика лецитиноподобного белка типа С у радужной форели // Индустрия питания|Food Industry. 2018. T. 3. № 4. C. 88-96. DOI 10.29141/2500-1922-2018-3-4-11

\section{Introduction}

Lectins are a superfamily of carbohydrate-binding proteins which are widely distributed throughout the animal kingdom (Holmskov et al., 2003). Based on the structure of the carbohydrate-recognition domains (CRDs), structural fold, distinct sugar specificities, functions and requirement of divalent cations, lectins are classified as C-type, F-type, I-type, L-type, P-type, R-type and S-type lectins and others (Bianchet et al., 2010; Lai et al., 2013; Mukherjee et al., 2014). Numerous lectins involved in defense against various infectious pathogens and reproduction have been identified and characterized within tissues and eggs of several species of fish, including Atlantic salmon (Salmo salar) (Zhang et al., 2001), rainbow trout (Oncorhynchus mykiss), Atlantic cod (Gadus morhua) (Bergsson et al., 2005), common carp (Cyprinus carpio) (Gonzalez et al., 2007), Japanese flounder (Paralichthys olivaceus) (Kondo et al., 2007), ayu (Plecoglossus altivelis) (Watanabe et al., 2008), Nile tilapia (Oreochromis niloticus) (Argayosa and Lee, 2009), sea bass (Dicentrarchus labrax) (Salerno et al., 2009), turbot (Scophthalmus maximus) (Zhang et al., 2010), bighead carp (Aristichthys nobilis) (Pan et al., 2010), grass carp (Ctenopharyngodon idellus) (Liu et al., 2011), channel catfish
(Zhang et al., 2012), rock bream (Oplegnathus fasciatus) (Park et al., 2012), tongue sole (Cynoglossus semilaevis) (Zhou and Sun, 2015), and so on.

C-type lectins were originally defined as a group of $\mathrm{Ca}^{2+}$-dependent (C-type) carbohydrate-binding proteins (Drickamer, 1988). Most C-type lectins consist of one CRD, whereas some have several or more CRDs. Each CRD usually possesses a characteristic double-loop stabilized by two conserved disulfide bridges (Zelensky and Gready, 2005). As C-type lectins can recognize and bind the specific carbohydrate patterns present on the surface of invading microorganisms, they are considered as pattern recognition receptors (PRR) that play important roles in non-self-recognition and clearance of invading pathogens (Poisa-Beiro et al., 2009). Besides functioning as pattern recognition receptors, C-type lectins can take part in various kinds of immune responses, including cytokine release (Tsutsui et al., 2007; Wei et al., 2010), phagocytosis (Luo et al., 2006), encapsulation and melanization (Ling and Yu, 2006), cell adhesion (Odintsova et al., 2001), aggregation (Zhang et al., 2009), antibacteria, fungi or virus activity (Willment and Brown, 2008; Liu et al., 2011; Huang et al., 2013), activating the comple- 
ment pathway, activating apoptosis by a complement-independent style (Zhang et al., 2012), and many other biological responses.

Rainbow trout are one of the most intensively studied fish species because of their importance as a food and sport fish (Young et al., 1998). To efficiently manage disease problems and provide knowledge for long-term enhancement in rainbow trout aquaculture production, the rainbow trout immune response to pathogen exposure should be studied thoroughly. The C-type lectin of teleost fish are important as tools for research and as targets for novel therapeutants. However, at present our understanding on the immunity of rainbow trout is poor. Considering that a number of various C-type lectin have been isolated and characterized in other fishes, C-type lectins may be primarily involved in rainbow trout immunity against a great variety of pathogens. In this study, we reported the cloning and characterization of a full-length cDNA of a C-type lectin-like protein gene from O. mykiss (designated as Om-CTLP). Furthermore, Om-CTLP mRNA expression profiles in different tissues and following both viral haemorrhagic septicemia virus (VHSV) and Aeromonas hydrophila (A. Hydrophila) infection, and characteristics of recombinant Om-CTLP protein following immunity response were also investigated.

Materials and Methods

O. mykiss with body weight of 150-200g were obtained from an aquatic product farms and acclimatized to laboratory pathogen-free conditions for two weeks. Before experiments, the pathogen-free status of the fish was confirmed by analysis for bacterial, parasitic and viral pathogens. For challenge experiments with VHSV or $A$. hydrophila, fish were injected with $10 \mu$ PBS per gram body weight, 10 $\mu$ VHSV suspended in PBS $(2 \times 108$ PFU ml-1) or 10 $\mu \mathrm{l}$. hydrophila resuspended in PBS $\left(\mathrm{OD}_{600}=0.2\right)$ intraperitoneally. The control group received individually an injection of $10 \mu$ PBS solution per gram body weight. The non-injected fish were used as blank group. Five individuals were killed and tissues including gill, heart, liver, kidney, intestine, spleen, and muscle were collected at $0,12,24,36,48,72$, 96,144 and $192 \mathrm{~h}$ after injection. Tissue samples were collected and frozen at $-70^{\circ} \mathrm{C}$ until analysis.

All fresh tissues (50-100 mg) were homogenized in the Trizol Reagent (Invitrogen, Carlsbad, USA), and total RNA was prepared according to the manufacturer's instruction, and then was digested with RNase-free DNase I (Promega, Madison, USA) to remove genomic DNA contamination. The cDNA was synthesized from $5 \mu$ l of total RNA by ExScript RT reagent kit (TaKaRa, Dalian, China) with oligo d (T) 18 as primer according to the manufacturer's instruction.
Using the cDNA prepared above as a template, highly conserved region of Om-CTLP was amplified with a pair of degenerate primers (Om-CTLP-F and Om-CTLP-R, Table 1) based on known C-type lectin gene sequence alignment from other species. The PCR amplification conditions of temperature profile was $94{ }^{\circ} \mathrm{C}$ for $5 \mathrm{~min}$, followed by 32 cycles of $94{ }^{\circ} \mathrm{C}$ for $30 \mathrm{~s}, 57^{\circ} \mathrm{C}$ for $30 \mathrm{~s}, 72{ }^{\circ} \mathrm{C}$ for $50 \mathrm{~s}$, and the final extension step at $72{ }^{\circ} \mathrm{C}$ for $10 \mathrm{~min}$. The PCR products were gel-purified and cloned into PMD18-T Vector (TaKaRa, Dalian, China) and sequenced.

The 3'-RACE and 5'-RACE were performed using the TaKaRa 3'-Full RACE Kit and the 5'-Full RACE Core Set Kit according to the kit manufacturer's manual, respectively. A total of $5 \mu \mathrm{g}$ RNA was reversely transcribed using the MMLV reverse transcriptase (TaKaRa) to obtain the first-strand cDNA. The 3 ' and 5' region sequences of Om-CTLP were both amplified by nested PCR using 3'-RACE primers (3' Om-CTLP-1 and 3' Om-CTLP-2, Table) and 5'-RACE primers (5'Om-CTLP-1 and 5' Om-CTLP-2, Table) which were based on the above amplified highly conserved region of the Om-CTLP cDNA fragment, respectively. The full-length cDNA sequences were confirmed by sequencing the PCR product amplified by primers FL-Om-CTLP-F and FL-Om-CTLP-R (Table) within the predicted $3^{\prime}$ and $5^{\prime}$ untranslated regions, respectively.

Results

A highly conserved core region sequence of 328 bp was amplified with primers mentioned above, and using the 3 '-RACE and 5'-RACE method, two cDNA 3' ends of 461 and 227 bp, two cDNA 5' ends of 484 and 267 bp were amplified by 3'- and 5'-RACE as well, respectively. The five nucleotide sequences above were assembled with DNAman software, and a 1,153 bp of single contig was acquired. To confirm that the resulting 1,153 bp consensus sequence represented a single mRNA of rainbow trout, primers FL-Om-CTLP-F and FL-Om-CTLP-R were designed spanning the coding region. Using these primers, a single 853 bp product was amplified. The fulllength cDNA of Om-CTLP was 1,153 bp, containing a $5^{\prime}$ untranslated region (UTR) of 62 nucleotides, a 723 bp open reading frame (ORF) which encoded 240 amino acids, and a 3' UTR of 368 nucleotides containing a canonical polyadenylation signal site (AATAAA) 18 bp upstream of the polyadenylation tail. The full-length cDNA sequence of Om-CTLP has been deposited in the GenBank database under accession number FJ607865. Blastp analysis indicated that the deduced protein sequence has significant homology to previously characterized C-type lectin proteins.

The expression of Om-CTLP mRNA in various tissues at $36 \mathrm{~h}$ post-injection was analyzed using real-time RT-PCR to assess the levels of Om-CTLPtran- 
Oligonucleotide primers

Олигонуклеотидные праймеры

\begin{tabular}{|c|c|c|}
\hline Name & Sequence $\left(5^{\prime}-3^{\prime}\right)$ & Application \\
\hline Om-CTLP-F & GGGTGGYTTCNTGTACTRGT & Gene cloning \\
\hline$O M-C T L P-R$ & GGACYACACVGNCCTCRCCT & \\
\hline 5' Om-CTLP-1 & TTGCTGTGCAGGATGCTAAG & 5'RACE \\
\hline 5' Om-CTLP-2 & TACTCAGATCCAACTTCAGG & \\
\hline 3' Om-CTLP-1 & CAGAGTAACACTCATGCCTG & 3'RACE \\
\hline 3' Om-CTLP-2 & TGTAAACGCGGTGGTAATCA & \\
\hline FL-OM-CTLP-F & TGATTGGCCTCTTGGTATCC & Confirming sequence \\
\hline FL-Om-CTLP-R & AATGCACGTTAGGGAAATGC & \\
\hline Q-Om-CTLP-F & ACTGGAGATGGGTGGACAAC & QPCR \\
\hline$Q-O m-C T L P-R$ & ATGCGGTGGTAGAGGAATTG & \\
\hline$Q-\beta$-actin- $F$ & TATGTGCAAAGCCGGATTCG & qPCR \\
\hline$Q-\beta$-actin-R & GTGACGATGCCATGCTCAAT & \\
\hline RE-Om-CTLP-F & TACTCAGAATTCTGTCCTGAGGGGTGGCTTCAT & Recombination \\
\hline$R E-O m-C T L P-R$ & TACTCACTCGAGTCAAGGAGAAGTAGTGGGGAA & \\
\hline
\end{tabular}

Note: $Y=C / T ; R=A / G ; V=A / G / C ;$ and $N=A / G / C / T ;$ restriction enzymes of EcoRI and Xhol sites were underlined.

scripts. Om-CTLP mRNA was detected in all tissues tested at low expression levels, and was dramatically up-regulated after bacterial or viral injection $(P<0.05)$ (Fig. 4). In two infected groups, the strongest expression were found all in the spleen, liver and kidney (Fig. 1).

Each bar represented the mRNA expression level of target gene relative to those in control group, Om-CTLP mRNA expression was measured in the gill, heart, liver, kidney, intestine, spleen, and muscle of rainbow trout $36 \mathrm{~h}$ after infection with VHSV or bacteria. The control groups were injected with PBS. Data are the means \pm SE of five rainbow trouts. Asterisks represent significant difference between treated group and control $(* P<0.05)$. Error bars showed the standard error.

The Om-CTLP expression in spleen was most up-regulated 8.5-fold by bacterial stimulation or 6.9-fold by viral. For fish VHSV disease, liver is one of the main affected organs (Liu et al. 2011), and $O m-C T L P$ in liver was the second most up-regulated 8.4-fold by bacterial stimulation or 6.6-fold by viral. Therefore, liver was selected to investigate the temporary expression profile of Om-CTLP mRNA after microorganisms challenge.

To analyze the effects of bacterial or viral stimulation on Om-CTLPgene expression in liver tissue, five fish from each group were dissected at each time point $(0,4,12,24,36,48,72,96$ and $144 \mathrm{~h}$ post-injection) and qRT-PCR assays were employed. No significant differences were observed between control and blank groups at any of the time points ( $P>0.05)$ (data not shown). In treated groups, the Om-CT$L P$ mRNA expressions levels were significantly in- creased at $12 \mathrm{~h}$ post-infection, reached highest level at $36 \mathrm{~h}$ post-infection $(P<0.05)$, and then gradually decreased, but they still kept relatively high levels until the fish became moribund $(P<0.05)$ (Fig. 2).

The control groups were injected with PBS, while the treated groups were infected with VHSV or $A$. hydrophila. Asterisks represent significant difference between treated group and control ( $* P<0.05)$. Error bars showed the standard error.

The data obviously showed that Om-CTLP expression levels were stimulated in infected animals, for both bacterial and viral stimulation $(P<0.05)$. The temporary expression profile of Om-CTLP between bacterial and viral stimulation was similar, just up-regulation extent was relatively less in viral stimulation.

The agglutination activity against $\mathrm{S}$. aureus and $A$. hydrophila of Om-CTLP was tested. In the presence of $\mathrm{Ca}^{2+}, \mathrm{Om}-C T L P$ can agglutinate Gram-positive and Gram-negative bacteria tested (Fig. 7). No agglutination activity was observed in the BSA plus $\mathrm{Ca}^{2+}$ control (Fig. 3).

A Gram-positive (S. aureus) and a Gram-negative bacteria ( $A$. hydrophila) were shown.

\section{Discussion}

C-type lectins play crucial roles in innate immunity and pathogen recognition. In this study, a C-type lectin-like protein (Om-CTLP) gene was cloned from rainbow trout, Oncorhynchus mykiss by rapid amplification of CDNA ends (RACE) PCR. The full-length CDNA of Om-CTLP was composed of 1,153 bp with a 723 bp open reading frame (ORF) that encodes a 240-residue protein with an estimated molecular mass of $27 \mathrm{kD}$ and a predicted isoelectric point of 


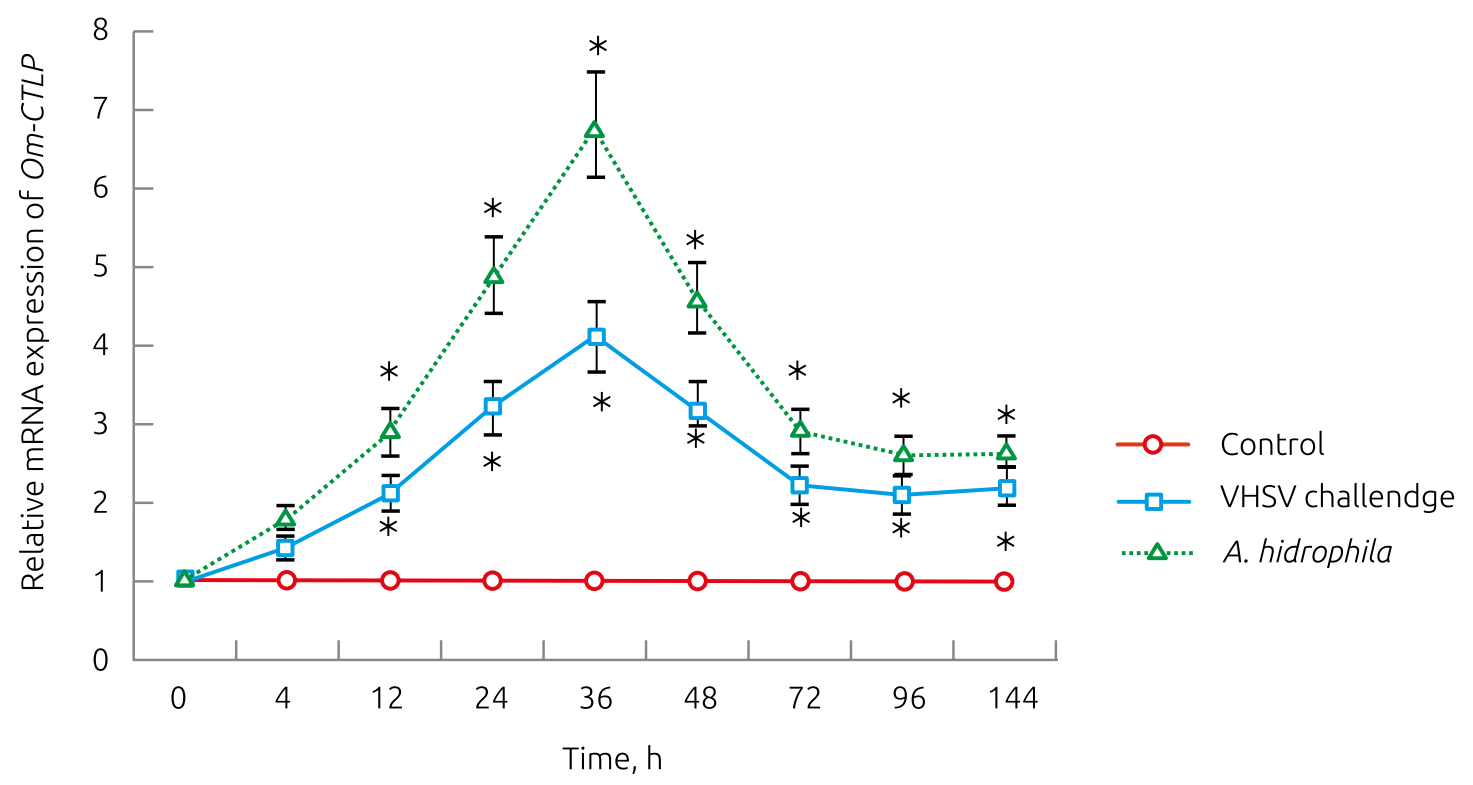

Fig. 1. Tissue distribution of Om-CTLP transcripts in rainbow trout

Puc. 1. Распределение лектин-подобного белка типа С в соединительной ткани радужной форели

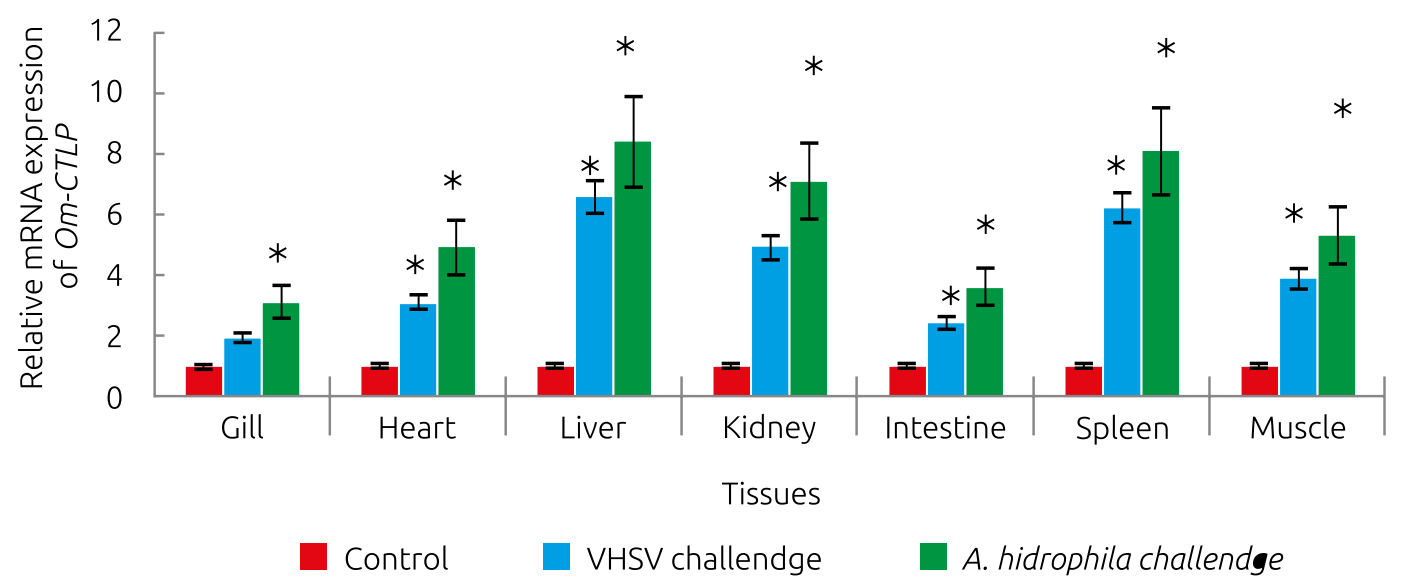

Fig. 2. The temporary expression profile of Om-CTLP mRNA after microorganisms challenge in liver using qRT-PCR Puс. 2. Временный профиль экспрессии иРНК лектин-подобного белка типа С радужной форели после введения микроорганизмов в печень с помощью ОТ-ПЦР

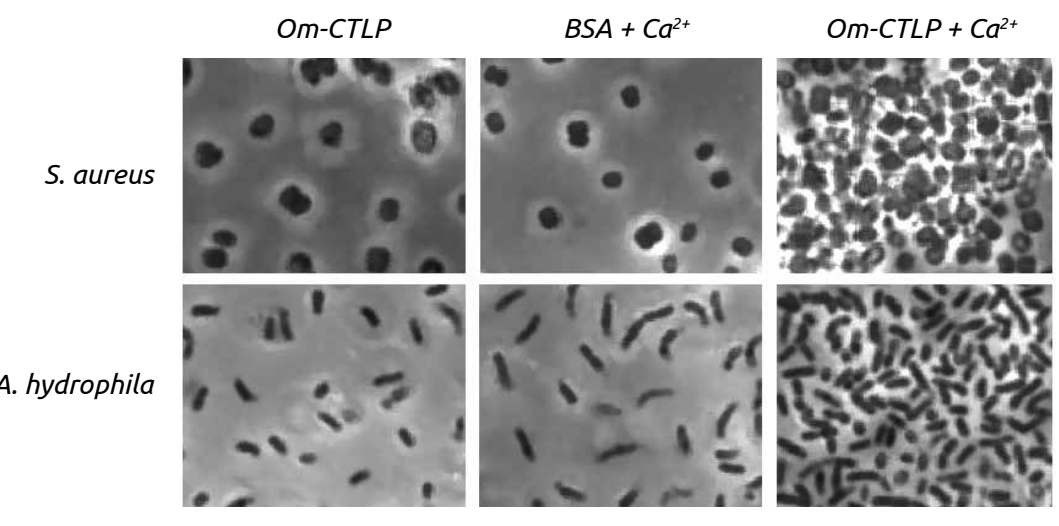

Fig. 3. Agglutination of bacteria by Om-CTLP

Puc. 3. Агглютинация бактерий лектин-подобным белком типа Су радужной форели 
5.48. The deduced amino acid sequence of Om-CT$L P$ possessed all conserved features crucial for the fundamental structure, such as the four cysteine residues (Cys ${ }^{128}-\mathrm{Cys}^{230}, \mathrm{Cys}^{207}-\mathrm{Cys}^{222}$ ) formed the carbohydrate recognition domain (CRD) internal disulfide bridges and the potential $\mathrm{Ca}^{2+} /$ carbohydrate-binding sites. Om-CTLP contains a transmembrane domain and a single CRD. Om-CTLP showed high similarity of 44-84\% with C-type lectins from other fish species. Quantitative RT-PCR (qRT-PCR) analysis showed Om-CTLP mRNA was constitutive expression in gill, heart, liver, kidney, intestine, spleen and muscle tissues in healthy fish and up-regulated under infection by bacteria or viruses. After being infected by Aeromonas hydrophila

\section{Bibliography}

1. Argayosa, A.M., Lee, Y.C., 2009. Identification of (L)-fucose-binding proteins from the Nile tilapia (Oreochromis niloticus L.) serum. Fish Shellfish Immunol. 27, 478-485.

2. Bergsson, G., Agerberth, B., Jörnvall, H., Gudmundsson, G.H., 2005. Isolation and identification of antimicrobial components from the epidermal mucus of Atlantic cod (Gadus morhua). FEBS Lett. 272, 4960-4969.

3. Bianchet, M.A., Odom, E.W., Vasta, G.R., Amzel, L.M., 2010. Structure and specificity of a binary tandem domain F-lectin from striped bass (Morone saxatilis). J Mol Biol. 401, 239-252.

4. Drickamer, K., 1988. Two distinct classes of carbohydrate-recognition domains in animal lectins. J Biol Chem. 263, 9557-9560.

5. Drickamer, K., 1993. Evolution of Ca(2+)-dependent animal lectins. Prog Nucleic Acid Res Mol Biol. 45, 207-232.

6. Gonzalez, S.F., Buchmann, K., Nielsen, M.E., 2007. Complement expression in common carp (Cyprinus carpio L.) during infection with Ichthyophthirius multifiliis. Dev Comp Immunol. 31, 576-586.

7. Holmskov, U., Thiel, S., Jensenius, J.C., 2003. Collectins and ficolins: humoral lectins of the innate immune defence. Annu Rev Immunol. 21, 547-578.

8. Huang, M., Song, X., Zhao, J, Mu, C., Wang, L., Zhang, H., Zhou, Z., Liu, X., Song, L., 2013. A C-type lectin (AiCTL-3) from bay scallop Argopecten irradians with mannose/galactose binding ability to bind various bacteria. Gene 531, 31-38.

9. Huang, X., Huang, Y., Shi, Y.R., Ren, Q., Wang, W., 2015. Function of a novel C-type lectin with two CRD domains from Macrobrachium rosenbergii in innate immunity. Dev Comp Immunol. 49, 121-126.

10. Huang, Y., Huang, X., Wang, Z., Tan, J.M., Hui, K.M., Wang, W., Ren, Q., 2014. Function of two novel single-CRD containing C-type lectins in innate immunity from Eriocheir sinensis. Fish Shellfish Immunol. 37, 313-321.

11. Kondo, H., Yeu Tzeh, A.G., Hirono, I., Aoki, T., 2007. Identification of a novel C-type lectin gene in Japanese flounder, Paralichthys olivaceus. Fish Shellfish Immunol, 23, 1089-1094. or viral haemorrhagic septicemia virus (VHSV), the expression of Om-CTLP were up-regulated from $12 \mathrm{~h}$ post-injection and lasted until the fish became moribund $(P<0.05)$. The recombinant Om-CTLPCRD can agglutinate both Gram-positive (Staphylococcus aureus) and Gram-negative bacteria (A. hydrophila) in a $\mathrm{Ca}^{2+}$-dependent manner. Further analysis showed that the recombinant $O m-C T L P$ can directly bind to all tested microorganisms (S. aureus, Bacillus thuringiensis, Bacillus subtilis, Escherichia coli, Vibrio natriegens, Vibrio parahaemolyticus, and A. hydrophila). These results suggest that Om-CTLP may have important roles in anti-bacterial and anti-viral immunity of rainbow trout.

\section{Библиографический список}

1. Argayosa, A.M., Lee, Y.C., 2009. Identification of (L)-fucose-binding proteins from the Nile tilapia (Oreochromis niloticus L.) serum. Fish Shellfish Immunol. 27, 478-485.

2. Bergsson, G., Agerberth, B., Jörnvall, H., Gudmundsson, G.H., 2005. Isolation and identification of antimicrobial components from the epidermal mucus of Atlantic cod (Gadus morhua). FEBS Lett. 272, 4960-4969.

3. Bianchet, M.A., Odom, E.W., Vasta, G.R., Amzel, L.M., 2010. Structure and specificity of a binary tandem domain F-lectin from striped bass (Morone saxatilis). J Mol Biol. 401, 239-252.

4. Drickamer, K., 1988. Two distinct classes of carbohydrate-recognition domains in animal lectins. J Biol Chem. 263, 9557-9560.

5. Drickamer, K., 1993. Evolution of Ca(2+)-dependent animal lectins. Prog Nucleic Acid Res Mol Biol. 45, 207-232.

6. Gonzalez, S.F., Buchmann, K., Nielsen, M.E., 2007. Complement expression in common carp (Cyprinus carpio L.) during infection with Ichthyophthirius multifiliis. Dev Comp Immunol. 31, 576-586.

7. Holmskov, U., Thiel, S., Jensenius, J.C., 2003. Collectins and ficolins: humoral lectins of the innate immune defence. Annu Rev Immunol. 21, 547-578.

8. Huang, M., Song, X., Zhao, J, Mu, C., Wang, L., Zhang, H., Zhou, Z., Liu, X., Song, L., 2013. A C-type lectin (AiCTL-3) from bay scallop Argopecten irradians with mannose/galactose binding ability to bind various bacteria. Gene 531, 31-38.

9. Huang, X., Huang, Y., Shi, Y.R., Ren, Q., Wang, W., 2015. Function of a novel C-type lectin with two CRD domains from Macrobrachium rosenbergii in innate immunity. Dev Comp Immunol. 49, 121-126.

10. Huang, Y., Huang, X., Wang, Z., Tan, J.M., Hui, K.M., Wang, W., Ren, Q., 2014. Function of two novel single-CRD containing C-type lectins in innate immunity from Eriocheir sinensis. Fish Shellfish Immunol. 37, 313-321.

11. Kondo, H., Yeu Tzeh, A.G., Hirono, I., Aoki, T., 2007. Identification of a novel C-type lectin gene in Japanese flounder, Paralichthys olivaceus. Fish Shellfish Immunol, 23, 1089-1094. 
12. Kong, P.F., Wang, L.L., Zhang, H., Song, X.Y., Zhou, Z., Yang, J.L., Qiu, L., Wang, L., Song, L., 2011. A novel C-type lectin from bay scallop Argopecten irradians (AiCTL-7) agglutinating fungi with mannose specificity. Fish Shellfish Immunol. 30, 836-344.

13. Lai, X.F., Gao, H., Kong, Jie., Wang, Q.Y., Meng, X.H., Yan, B.L., Chen, B.Y., 2013. Genomic organization and promoter characterization of FcCTL, a C-type lectin-like protein in Fenneropenaeus chinensis. Gene 518, 376-380.

14. Ling, E.J., Yu, X.Q., 2006. Cellular encapsulation and melanization are enhanced by immulectins, pattern recognition receptors from the tobacco hornworm Manduca sexta. Dev Comp Immunol. 30, 289299.

15. Liu, F., Li, J.L., Fu, J.J., Shen, Y.B., Xu, X.Y., 2011. Two novel homologs of simple C-type lectin in grass carp (Ctenopharyngodon idellus): potential role in immune response to bacteria. Fish Shellfish Immunol. 31, 765-773.

16. Luo, T., Yang, H.J., Li, F., Zhang, X.B., Xu, X., 2006. Purification, characterization and CDNA cloning of a novel lipopolysaccharide-binding lectin from the shrimp Penaeus monodon. Dev Comp Immunol. 30, 607-617.

17. Mann, K., Weiss, I.M., Andre, S., Gaius, H., Fritz, M., 2000. The aminoacid sequence of the abalone (Haliotis Laevigata) nacre protein perlucin. Eur J Biochem. 267, 5257-5264.

18. Mukherjee, S., Zheng, H., Derebe, M.G., Callenberg, K.M., Partch, C.L., Rollins, D., Propheter, D.C., Rizo, J., Grabe, M., Jiang, Q.X., Hooper, L.V., 2014. Antibacterial membrane attack by a pore-forming intestinal C-type lectin. Nature 505,103-107.

19. Mu, X., Pridgeon, J.W., Klesius, P.H., 2013. Comparative transcriptional analysis reveals distinct expression patterns of channel catfish genes after the first infection and re-infection with Aeromonas hydrophila. Fish Shellfish Immunol. 35, 1566-1576.

20. Odintsova, N.A., Belogortseva, N.I., Khomenko, A.V., Chikalovets, I.V., Luk'yanov, P.A., 2001. Effect of lectin from the ascidian on the growth and the adhesion of HeLa cells. Mol Cell Biochem. 221, 133138.

21. Pan, S.K., Tang, J., Gu, X.H., 2010. Isolation and characterization of a novel fucose-binding lectin from the gill of bighead carp (Aristichthys nobilis). Vet Immunol Immunopathol. 133, 154-164.

22. Park, H.J., Kim, J.W., Kim, E.G., Kim, H.N., Chae, Y.S., Jeong, J.M., Kim, D.H., Park, C.I., 2012. Molecular cloning and expression analysis of two distinct F-type lectins from the rock bream, Oplegnathus fasciatus. Dev Comp Immunol, 36, 230-235.

23. Poisa-Beiro, L., Dios, S., Ahmed, H., Vasta, G.R., Martínez-López, A., Estepa, A., Alonso-Gutiérrez, J., Figueras, A., Novoa, B., 2009. Nodavirus infection of sea bass (Dicentrarchus labrax) induces up-regulation of galectin-1 expression with potential anti-inflammatory activity. J Immunol.183, 6600-6611.

24. Reyes-Becerril, M., López-Medina, T., Ascencio-Valle, F., Esteban MÁ., 2011. Immune response of gilthead seabream (Sparus aurata) following experimental infection with Aeromonas hydrophila. Fish Shellfish Immunol. 31, 564-570.

25. Salerno, G., Parisi, M.G., Parrinello, D., Benenati, G., Vizzini, A., Vazzana, M., Vasta, G.R., Cammarata, M., 2009. F-type lectin from the sea bass (Dicentrarchus labrax): purification, cDNA cloning, tissue expression and localization, and opsonic activity. Fish Shellfish Immunol. 27, 143-153.

26. Tasumi, S., Ohira, T., Kawazoe, I., Suetake, H., Suzuki, Y., Aida, K., 2002. Primary structure and characteristics of a lectin from skin mucus of the Japanese eel Anguilla japonica. J Biol Chem. 277, 2730527311.
12. Kong, P.F., Wang, L.L., Zhang, H., Song, X.Y., Zhou, Z., Yang, J.L., Qiu, L., Wang, L., Song, L., 2011. A novel C-type lectin from bay scallop Argopecten irradians (AiCTL-7) agglutinating fungi with mannose specificity. Fish Shellfish Immunol. 30, 836-344.

13. Lai, X.F., Gao, H., Kong, Jie., Wang, Q.Y., Meng, X.H., Yan, B.L., Chen, B.Y., 2013. Genomic organization and promoter characterization of $\mathrm{FcCTL}$, a C-type lectin-like protein in Fenneropenaeus chinensis. Gene 518, 376-380.

14. Ling, E.J., Yu, X.Q., 2006. Cellular encapsulation and melanization are enhanced by immulectins, pattern recognition receptors from the tobacco hornworm Manduca sexta. Dev Comp Immunol. 30, 289299.

15. Liu, F., Li, J.L., Fu, J.J., Shen, Y.B., Xu, X.Y., 2011. Two novel homologs of simple C-type lectin in grass carp (Ctenopharyngodon idellus): potential role in immune response to bacteria. Fish Shellfish Immunol. 31, 765-773.

16. Luo, T., Yang, H.J., Li, F., Zhang, X.B., Xu, X., 2006. Purification, characterization and cDNA cloning of a novel lipopolysaccharide-binding lectin from the shrimp Penaeus monodon. Dev Comp Immunol. 30, 607-617.

17. Mann, K., Weiss, I.M., Andre, S., Gaius, H., Fritz, M., 2000. The aminoacid sequence of the abalone (Haliotis Laevigata) nacre protein perlucin. Eur J Biochem. 267, 5257-5264.

18. Mukherjee, S., Zheng, H., Derebe, M.G., Callenberg, K.M., Partch, C.L., Rollins, D., Propheter, D.C., Rizo, J., Grabe, M., Jiang, Q.X., Hooper, L.V., 2014. Antibacterial membrane attack by a pore-forming intestinal C-type lectin. Nature 505,103-107.

19. Mu, X., Pridgeon, J.W., Klesius, P.H., 2013. Comparative transcriptional analysis reveals distinct expression patterns of channel catfish genes after the first infection and re-infection with Aeromonas hydrophila. Fish Shellfish Immunol. 35, 1566-1576.

20. Odintsova, N.A., Belogortseva, N.I., Khomenko, A.V., Chikalovets, I.V., Luk'yanov, P.A., 2001. Effect of lectin from the ascidian on the growth and the adhesion of HeLa cells. Mol Cell Biochem. 221, 133138.

21. Pan, S.K., Tang, J., Gu, X.H., 2010. Isolation and characterization of a novel fucose-binding lectin from the gill of bighead carp (Aristichthys nobilis). Vet Immunol Immunopathol. 133, 154-164.

22. Park, H.J., Kim, J.W., Kim, E.G., Kim, H.N., Chae, Y.S., Jeong, J.M., Kim, D.H., Park, C.I., 2012. Molecular cloning and expression analysis of two distinct F-type lectins from the rock bream, Oplegnathus fasciatus. Dev Comp Immunol, 36, 230-235.

23. Poisa-Beiro, L., Dios, S., Ahmed, H., Vasta, G.R., Martínez-López, A., Estepa, A., Alonso-Gutiérrez, J., Figueras, A., Novoa, B., 2009. Nodavirus infection of sea bass (Dicentrarchus labrax) induces up-regulation of galectin-1 expression with potential anti-inflammatory activity. J Immunol.183, 6600-6611.

24. Reyes-Becerril, M., López-Medina, T., Ascencio-Valle, F., Esteban MÁ., 2011. Immune response of gilthead seabream (Sparus aurata) following experimental infection with Aeromonas hydrophila. Fish Shellfish Immunol. 31, 564-570.

25. Salerno, G., Parisi, M.G., Parrinello, D., Benenati, G., Vizzini, A., Vazzana, M., Vasta, G.R., Cammarata, M., 2009. F-type lectin from the sea bass (Dicentrarchus labrax): purification, cDNA cloning, tissue expression and localization, and opsonic activity. Fish Shellfish Immunol. 27, 143-153.

26. Tasumi, S., Ohira, T., Kawazoe, I., Suetake, H., Suzuki, Y., Aida, K., 2002. Primary structure and characteristics of a lectin from skin mucus of the Japanese eel Anguilla japonica. J Biol Chem. 277, 2730527311. 
27. Tsutsui, S., Iwamoto, K., Nakamura, 0., Watanabe, T., 2007. Yeast-binding C-type lectin with opsonic activity from conger eel (Conger myriaster) skin mucus. Mol Immunol. 44, 691-702.

28. Watanabe, Y., Shiina, N., Shinozaki, F., Yokoyama, H., Kominami, J., Nakamura-Tsuruta, S., Hirabayashi, J., Sugahara, K., Kamiya, H., Matsubara, H., Ogawa, T., Muramoto, K., 2008. Isolation and characterization of l-rhamnose-binding lectin, which binds to microsporidian Glugea plecoglossi, from ayu (Plecoglossus altivelis) eggs. Dev Comp Immunol. 32, 487-499.

29. Wei, J.G., Xu, D., Zhou, J.G., Cui, H.C., Yan, Y., Ouyang, Z.L., Gong, J., Huang, Y., Huang, X., Qin, Q., 2010. Molecular cloning, characterization and expression analysis of a C-type lectin (EC-CTL) in orangespotted grouper, Epinephelus coioides. Fish Shellfish Immunol. 28,178-186.

30. Willment, J.A., Brown, G.D., 2008. C-type lectin receptors in antifungal immunity. Trends Microbiol.16, 27-32.

31. Young, W.P., Wheeler, P.A., Coryell, V.H., Keim, P., Thorgaard, G.H., 1998. A detailed linkage map of rainbow trout produced using doubled haploids. Genetics 148, 839-850.

32. Yu, S., Yang, H., Chai, Y., Liu, Y., Zhang, Q., Ding, X., Zhu, Q., 2013. Molecular cloning and characterization of a C-type lectin in roughskin sculpin (Trachidermus fasciatus). Fish Shellfish Immunol. 34, 582-592.

33. Zelensky, A.N., Gready, J.E., 2005. The C-type lectin-like domain superfamily. FEBS Lett. 272, 6179-6217.

34. Zhang, H., Nichols, K., Thorgaard, G.H., Ristow, S.S., 2001. Identification, mapping, and genomic structural analysis of an immunoreceptor tyrosine-based inhibition motif-bearing C-type lectin from homozygous clones of rainbow trout (Oncorhynchus mykiss). Immunogenetics 53, 751-759.

35. Zhang, H., Peatman, E., Liu, H., Feng, T.T., Chen, L.Q., Liu, Z.J., 2012. Molecular characterization of three L-type lectin genes from channel catfish, Ictalurus punctatus and their responses to Edwardsiella ictaluri challenge. Fish Shellfish Immunol. 32, 598-608.

36. Zhang, H., Peatman, E., Liu, H., Niu, D., Feng, T., Kucuktas, H., Waldbieser, G., Chen, L., Liu, Z., 2012. Characterization of a mannose-binding lectin from channel catfish (Ictalurus punctatus). Res Vet Sci. 92, 408-413.

37. Zhang, H., Robison, B., Thorgaard, G.H., Ristow, S.S., 2000. Cloning, mapping and genomic organization of a fish C-type lectin gene from homozygous clones of rainbow trout (Oncorhynchus mykiss). Biochim Biophys Acta. 1494, 14-22.

38. Zhang, M., Hu, Y.H., Sun, L., 2010. Identification and molecular analysis of a novel $C$-type lectin from Scophthalmus maximus. Fish Shellfish Immunol. 29, 82-88.

39. Zhang, X.W., Xu, W.T., Wang, X.W., Mu, Y., Zhao, X.F., Yu, X.Q., Wang, J.X., 2009. A novel C-type lectin with two CRD domains from Chinese shrimp Fenneropenaeus chinensis functions as a pattern recognition protein. Mol Immunol. 46, 1626-1637.
27. Tsutsui, S., Iwamoto, K., Nakamura, 0., Watanabe, T., 2007. Yeast-binding C-type lectin with opsonic activity from conger eel (Conger myriaster) skin mucus. Mol Immunol. 44, 691-702.

28. Watanabe, Y., Shiina, N., Shinozaki, F., Yokoyama, H., Kominami, J., Nakamura-Tsuruta, S., Hirabayashi, J., Sugahara, K., Kamiya, H., Matsubara, H., Ogawa, T., Muramoto, K., 2008. Isolation and characterization of l-rhamnose-binding lectin, which binds to microsporidian Glugea plecoglossi, from ayu (Plecoglossus altivelis) eggs. Dev Comp Immunol. 32, 487-499.

29. Wei, J.G., Xu, D., Zhou, J.G., Cui, H.C., Yan, Y., Ouyang, Z.L., Gong, J., Huang, Y., Huang, X., Qin, Q., 2010. Molecular cloning, characterization and expression analysis of a C-type lectin (EC-CTL) in orangespotted grouper, Epinephelus coioides. Fish Shellfish Immunol. 28,178-186.

30. Willment, J.A., Brown, G.D., 2008. C-type lectin receptors in antifungal immunity. Trends Microbiol.16, 27-32.

31. Young, W.P., Wheeler, P.A., Coryell, V.H., Keim, P., Thorgaard, G.H., 1998. A detailed linkage map of rainbow trout produced using doubled haploids. Genetics 148, 839-850.

32. Yu, S., Yang, H., Chai, Y., Liu, Y., Zhang, Q., Ding, X., Zhu, Q., 2013. Molecular cloning and characterization of a C-type lectin in roughskin sculpin (Trachidermus fasciatus). Fish Shellfish Immunol. 34, 582-592.

33. Zelensky, A.N., Gready, J.E., 2005. The C-type lectin-like domain superfamily. FEBS Lett. 272, 6179-6217.

34.Zhang, H., Nichols, K., Thorgaard, G.H., Ristow, S.S., 2001. Identification, mapping, and genomic structural analysis of an immunoreceptor tyrosine-based inhibition motif-bearing C-type lectin from homozygous clones of rainbow trout (Oncorhynchus mykiss). Immunogenetics 53, 751-759.

35. Zhang, H., Peatman, E., Liu, H., Feng, T.T., Chen, L.Q., Liu, Z.J., 2012. Molecular characterization of three L-type lectin genes from channel catfish, Ictalurus punctatus and their responses to Edwardsiella ictaluri challenge. Fish Shellfish Immunol. 32, 598-608.

36. Zhang, H., Peatman, E., Liu, H., Niu, D., Feng, T., Kucuktas, H., Waldbieser, G., Chen, L., Liu, Z., 2012. Characterization of a mannose-binding lectin from channel catfish (Ictalurus punctatus). Res Vet Sci. 92, 408-413.

37. Zhang, H., Robison, B., Thorgaard, G.H., Ristow, S.S., 2000. Cloning, mapping and genomic organization of a fish C-type lectin gene from homozygous clones of rainbow trout (Oncorhynchus mykiss). Biochim Biophys Acta. 1494, 14-22.

38. Zhang, M., Hu, Y.H., Sun, L., 2010. Identification and molecular analysis of a novel $C$-type lectin from Scophthalmus maximus. Fish Shellfish Immunol. 29, 82-88.

39. Zhang, X.W., Xu, W.T., Wang, X.W., Mu, Y., Zhao, X.F., Yu, X.Q., Wang, J.X., 2009. A novel C-type lectin with two CRD domains from Chinese shrimp Fenneropenaeus chinensis functions as a pattern recognition protein. Mol Immunol. 46, 1626-1637. 
Информация 06 авторах / Information about Authors

\section{Wang, Jiaqing}

\section{Джиакинг Ванг}

тел./Phone: +86 (024) 580143

E-mail:jiaqing5212@163.com

\section{Potoroko,} Irina Yurievna

\section{Потороко}

Ирина Юрьевна

Тел./Phone: +7 (351) 267-93-80

E-mail:potorokoii@susu.ru

\section{Tsirulnichenko,} Lina Aleksandrovna

Цирульниченко

Лина Александровна

тел./Phone: +7 (351) 267-93-80

E-mail: tcirulnichenkola@susu.ru
Professor, Director of the College of Life Engineering

Shenyang Institute of Technology

113122, People's Republic of China, Fushun, Binhe Road, No.1

Профессор, директор Научно-производственного колледжа Шэньянский технологический институт

113122, Китайская Народная Республика, Фушунь, Бине Роад, 1

Doctor of Technical Science, Professor, Head of the Food and Biotechnology Department South Ural State University

454080, Russian Federation, Chelyabinsk, Lenina Ave, 85

Доктор технических наук, профессор, заведующий кафедрой пищевых и биотехнологий Южно-Уральский государственный университет

454080, Российская Федерация, г. Челябинск, пр. Ленина, 85

ORCID: https://orcid.org/0000-0003-1941-6754

Candidate of Technical Science, Associate Professor of the Food and Biotechnology Department South Ural State University

454080, Russian Federation, Chelyabinsk, Lenina Ave, 85

Кандидат технических наук, Доцент кафедры пищевых и биотехнологий Южно-Уральский государственный университет

454080, Российская Федерация, г. Челябинск, пр. Ленина, 85

ORCID: https://orcid.org/0000-0002-9686-8490 